\title{
A Librarian's Reflections on the Emerging Bibliography of Film Music ${ }^{1}$
}

\author{
Desmond Maley \\ Laurentian University
}

The impetus for this paper began with an observation: there are more books coming out about film music than ever before. I wondered: has anyone ever talked about this compositional genre at our CAML conferences? A search of both the index and full-text of our online CAML Newsletter/Review did not reveal anything. Certainly film music has arrived in university curriculums in recent years. Many institutions are now teaching courses on film music, including Laurentian University. First offered in 2005, Laurentian's course is a three-credit (half term) elective taught by Robert Hall of the Music Department. It is also the department's most heavily enrolled course, sharing the lead with the six-credit elective the department offers on pop music. As a result I have been ordering film-music books. At first I was surprised that there did not seem to be many. Now, however, the scales are tipping in the other direction.

Once I began investigating the topic, it did not take long to realize that film music studies are having a growing impact on research. According to Anderson and Sadoff's Music and Image Bibliography, published online in 2003, there were only twenty-two dissertations written from 1970 to 1989 . Contrast that with the seventy-six that were written during the twelve-year period from 1990 to 2002.

Formerly the literature was scattered, lacking a critical mass or centre. For example, there were no dedicated journals of a scholarly nature. Now there are three. Music and the Moving Image, published by Illinois University Press, is in its third volume this year. The similarly titled Music, Sound, and the Moving Image describes itself, on the Liverpool University Press site, as "the first international scholarly journal devoted to the study of the interaction between music and sound with the entirety of moving image media." This journal first appeared in 2007. Finally there is The Journal of Film Music, published by Equinox, which has appeared irregularly since 2002.

${ }^{1}$ This article is an expanded version of a conference paper titled "Reel Sound: The Burgeoning Bibliography of Film Music," presented at the annual conference of the Canadian University Music Society/Canadian Association of Music Libraries, Archives and Documentation Centres at the University of Regina in June 2010.

(C) 2010 The author and the Canadian Association of Music Libraries, Archives, and Documentation Centres / L'auteur et l'Association canadienne des bibliothèques, archives et centres de documentation musicaux. 
Music has been a part of film since film's inception in the mid-1890s, but it did not receive much scholarly scrutiny until the 1980s. I can recall when Steven Wescott's Comprehensive Bibliography of Music for Film and Television was published in 1985. I was a newly minted librarian at the time at the small college where the Laurentian program (a four-year BA with a music concentration) was taught. I did not order a copy. My rationale: who would look at it? In fact I was right. I never had a question about film music, any discussion of which also failed to materialize in the standard texts of the day. The exception was Aaron Copland's chapter in the 1957 edition of What to Listen for in Music, which remains one of the best introductions to the film composer's art.

Only recently did I at last get Wescott's out-of-print survey through interlibrary loan and spend some time with it. There are over 6,300 entries. The literature is vast but also thin. Most of the articles are only a few pages in length. A grand total of eleven entries (with eight "see also" references to elsewhere in the compendium) are slotted under the category, "Surveys of Film Music Research," and here again they are brief. There was, however, one important exception. Martin Miller Marks' review essay, "Film Music: The Material, Literature and Present State of Research," which first appeared in Notes in 1979, is indispensable reading. A revised version updating the literature through the 1980s is published in his 1997 book, Music and the Silent Film.

Also valuable is Robynn Stilwell's "Music in Films: A Critical Review of Literature, 19801996," which Robert Hall pointed out to me. It was published in the inaugural issue of The Journal of Film Music in 2002. I was surprised, however, by her comments about Christopher Palmer, who authored many of the articles related to film in the New Grove Dictionary of Music and Musicians. Although she praises some of his work, she clearly feels most of the scholarship is not strong. The unresolved question for me is whether Palmer's approach reflects the state of the scholarly literature at the time (1980). Finally, I admire and recommend Annette Davison's Hollywood Theory, Non-Hollywood Practice (2004). The first three chapters are a sustained and thoughtful review of a number of the major authors in the field over the years.

Parenthetically, I would be remiss not to note that a bibliography is soon to be published by Scarecrow Press: Warren D. Sherk's Film Music: A Guide to Books, Articles and Composer Interviews. The bibliography will cover 100 years from 1906-2005. Sherk, who is the Music Specialist at the library of the Academy of Motion Picture Arts and Sciences in Los Angeles, told me he had worked at the project since the early 1980s.

In the early 1990s I spent a sabbatical developing a librarian's perspective on the emerging literature for Gerontology. I developed what I called "subject literature expertise" through journaling, keeping a card index of all the works consulted, interviews with faculty, and visits to other library collections. A similar approach has worked with respect to developing my "subject literature" knowledge of film music, although the time frame unfortunately has been far shorter, and all of my "visiting" has been electronic, either to web sites or through email.

It strikes me there are some functional similarities between the two literatures. For instance, film music, like Gerontology, has always had a professional practice literature. From the silent era, this would include Erno Rapée's Encyclopedia of Music for Pictures (1925), a landmark compilation of specially composed pieces indexed by mood or action. From this compendium the 
accompanist would pick music best suited for particular scenes. There is scholarly debate over the nature and extent of accompaniment during the silent era.

Guides and manuals comprise another segment of the professional practice literature. Current examples are On the Track: A Guide to Contemporary Film Scoring by Fred Karlin and Rayburn Wright and Sound Design: The Expressive Power of Music, Voice and Sound Effects in Cinema by David Sonnenschein. Trade publications (Film Score Monthly is an example) and professional societies like the Guild of Canadian Film Composers also fall under this rubric. The latter has a searchable database for its membership.

Film music, like Gerontology, has a large corpus of narrative literature. In Gerontology there has been interest in scholarly circles in reminiscence, autobiography and life review. In contrast, the prime narrative vehicle in film music has been the published interview. Wescott's bibliography, for instance, is replete with entries for articles of this kind. A current example would be Christian Desjardin's book, Inside Film Music: Composers Speak. There are few publications by scholarly publishers, however. Indeed this literature, unlike in Gerontology, is looked upon with skepticism because of its variable quality. Nonetheless some of it is worthwhile reading.

Film music parallels Gerontology in that advocacy is another dimension of the literature. In the case of film music, this means the concern for preservation. The Film Music Society was founded in 1983 as the Society for the Preservation of Film Music. Preservation also informs the mission of the Film Music Roundtable of the Music Library Association, founded in 1986. There is unpublished material in collections across North America, much of which is difficult to locate and/or inaccessible. And of course, an immense amount has already been lost. It raises the question: what steps are we Canadian librarians and archivists taking to preserve the papers of film composers? Perhaps we need our own Canadian roundtable.

With respect to the educational literature for film music, the first appreciation book did not appear until 1998, namely Larry Timm's The Soul of Cinema, which was greatly expanded in its 2003 edition. In 2006, Roger Hickman's Reel Music was published; this is the text used at Laurentian University. Both are chronological tours of Hollywood with commentaries on a number of landmark films. They contrast with Peter Larsen's Film Music (2008), originally published in Norway in 2005. Larsen's is a more theoretical approach, with a chapter on the psychology of film music and several detailed case studies.

Also of interest is Hearing the Movies: Music and Sound in Film History by James Buhler, David Neumeyer, and Rob Deemer (2008). It discusses the relationship between the sound and image tracks, and illustrates how sound and music may be analyzed in films. A substantial portion of the book is devoted to the evolution of sound technology, including high fidelity, Dolby stereo and digital.

Turning to recordings, the Naxos Music Library has over 500 film-related recordings. The Classical Music Library is about to add 400 classic soundtracks and it already has the Chandos Movie series. There also are specialty record labels such as Varese Sarabande, Intrada and Tribute Film Classics. 
The three videos used in the Laurentian course are worth noting. Directed by Joshua Waletzky, Music for the Movies - Bernard Herrmann (1992) chronicles the life and work of one of cinema music's acknowledged masters. Music for the Movies - The Hollywood Sound (1995), also directed by Waletzky, features an interview with David Raksin and a number of film excerpts with contemporary orchestral performances of music from the Hollywood Golden Age. And Lights, Action, Music (2007) features interviews with a number of contemporary composers.

The Bibliography of Online Resources in Film Music is a splendid web site compiled by Patrick Dorian, a music professor at East Stroudsberg University of Pennsylvania. It lists books, reference works, journals, composer web sites, interviews, case studies, organizations, conferences, and National Public Radio broadcasts on the subject. The annotations are extensive and the site is regularly updated.

With respect to the research literature, instead of compiling a booklist, I decided to follow the librarian's adage that we should study publishing houses. I also contacted a number of editors. The university presses are active. The Music, Popular Song and Film Music division of Oxford University Press has a number of titles, including the soon-to-be-published Hollywood Film Music Reader, an anthology of composers' writings. Oxford's Music/Media Series is under the editorship of Daniel Goldmark, a music professor at Case Western University. Launched in 2006, the series has several books that are either published or forthcoming. Goldmark himself has also written a study of Hollywood cartoon music (Tunes for 'Toons, 2005).

Edinburgh University Press, under the editorship of Kevin Donnelly of the University of Southampton, also has several books in its Music and Moving Image Series. There is one forthcoming publication, Music Video and the Politics of Representation (2011).

Cambridge University Press published Mervyn Cooke's massive History of Film Music in 2008. Over 1,700 films are listed in its index and it also has a nineteen-page bibliography. Cooke's history spans a number of national cinemas worldwide - but not Canada's, although he does pay homage to the work of the Scottish-Canadian animator, Norman McLaren. It should also be noted that Cooke wrote the authoritative article on film music for the second edition of The New Grove Dictionary of Music and Musicians (2001) that is available on the Oxford Music portal.

The University of California Press has several entries including How the West Was Sung (2007) by Kathryn Kalinak, which analyzes director John Ford's films. Forthcoming is an anthology, Celluloid Symphonies, edited by Julie Hubbert of the University of South Carolina.

Besides the university presses there are other publishers of film music research. Routledge's Music and Screen Media Series, under the editorship of Neil Lerner, has a recently published book on the horror film. Forthcoming is a book on music in television, edited by James Deaville.

Routledge has also published James Wierzbicki's Film Music: A History (2009). This excellent study analyzes how film music evolved in the context of changes in the industry, technology, and society. The depth of the research is revealed in the notes and the quotations that punctuate the narrative. 
The Scarecrow Press series of film score guides is reminiscent of the Norton Critical Scores and the Cambridge Music Handbooks. Each volume is an in-depth exploration of the music crafted for a particular film, such as Erich Wolfgang Korngold's The Adventures of Robin Hood (2007). Forthcoming studies include Nino Rota's music for The Godfather trilogy and Zbigniew Preisner's music for the Three Colors trilogy. The series is under the editorship of Kate Daubney of the University of Leeds. Other handbooks are in the works (Rebecca, Ben-Hur, and On the Waterfront). This summer, Scarecrow is also publishing A Research Guide to Film and Television Music in the United States by Jeannie Gayle Pool and H. Stephen Wright.

Equinox Books, a new publisher founded in London in 2003, has a series under the editorship of Mark Evans, an Australian scholar. Among the publications in preparation is a three-volume Encyclopedia of Film Music and Sound that will be the first major reference work on the subject. Evans indicates that work is progressing well on the project, which is expected to be completed in 2013. Canadian contributors are welcome.

The field already has its first scholarly handbook in Sound and Music in Film and Visual Media (2009), published by Continuum under the editorship of Graeme Harper. This ambitious, wideranging survey explores the intersections of sound and music with technology, culture, genre, theoretical approaches and biography. Altogether there are forty-seven essays, with extensive bibliographies, by an international group of authors. The same publisher has also reprinted Theodor Adorno and Hanns Eisler's Composing for the Films, a classic of Marxist scholarship that first appeared in 1947.

McFarland has issued a number of titles in the past decade. They include Music and Mythmaking in Film (2008) by Timothy Scheurer and Sounds of the Future: Essays on Music in Science Fiction Film (2010), edited by Mathew J. Bartkowiak.

Ashgate is perhaps the most prolific publisher of popular music studies. It has six film-music books listed in its Popular and Folk Music series, and is planning to publish a book titled Popular Music in Film and Television sometime next year.

I could go on. But the point of this snapshot tour is to illustrate that the tectonic plates of scholarship have shifted. Film music is firmly planted on the research agenda of many institutions and publishers. Second, there is a trend towards analyzing pop music in films and soundtracks around the world, including Bollywood. And third, the music of the small screen, television, has overcome its formerly "low" status and is receiving more attention as well. The same can be said of the music of video games.

Film music scholarship has been influenced by the theoretical approaches of film studies. For instance, Claudia Gorbman's seminal book, Unheard Melodies (1987), is a psychoanalytic study. The Scarecrow Handbooks on the other hand are more traditional - or "neo-formalist" in the lexicon of film studies. Film music is still a young field. Both study and teaching are a challenge. Royal S. Brown's tome, Overtones and Undertones (1994), though impressive in many ways, opens with a rather awkward primer on the major-minor scale system. Yet it reflects the fact that some readers have no music background, others have no film background, and still others have neither. 
Meanwhile, what about Canada? Let me quote from the "Film Scores" article of the 1981 edition of The Encyclopedia of Music in Canada: "By 1980 a detailed and analytical history of Canadian music for feature films had yet to be written, and no retrospective production record existed. This report will confine itself therefore to a brief survey, based on incomplete documentation, taking into account the fact that because production companies often have a short and tenuous existence, there are seldom archives that can be studied" (p. 330).

This assessment, which remains to this day on the online EMC2 Historica site, is, in fact, an accurate reflection of the current situation. The bibliography has been updated, but the article itself has not been substantively rewritten. There are books available on Canadian film, but most are on the "great directors" or are historical studies. I am not aware of any Canadian scholar who is currently writing about Canadian film composers, although there are resources and fonds that could be consulted at Library and Archives Canada and other institutions.

A biography of Louis Applebaum, by Walter Pitman, did appear in 2002. Applebaum was one of the leading figures of his day when it came to writing for film, theatre and television. However, the focus of the book is on his career as an arts administrator, not as a composer.

But there is one major publication that has received little critical attention: Mychael Danna's The Ice Storm, by Miguel Mera, published in 2007 as part of the Scarecrow series mentioned previously. Mera, who teaches at the Royal College of Music in London, provides a thorough, scholarly account of Danna's life, career and working methods. Particular attention is paid to Danna's music for the film The Ice Storm, directed by Ang Lee. Danna, a University of Toronto music graduate, is known especially for his work with director Atom Egoyan. Their collaboration was explored in a doctoral thesis by Michelle Bozynski in 2004. Bozynski also discusses the work of film composers Lesley Barber and Mark Korven in director Patricia Rozema's films. The most prominent Canadian film composer is Howard Shore. Perhaps someday there will be a book on his collaboration with David Cronenberg.

To sum up, this literature is of growing significance. University music curriculums are changing and this in turn is affecting faculty hiring, scholarship and the direction of research. Consequently, as librarians we need to develop and refine our "subject literature" knowledge in this area. We should also be in contact with our colleagues in film studies to further our understanding of the methodologies of the field. And in terms of the future development of our collections, it is essential to complement books with relevant video and sound recordings. Certainly it was a source of frustration for me to encounter case studies where recordings were not available for consultation. Finally, we should advocate the importance of preservation and make efforts to identify composer papers that ought to be included in archives or special collections. In these ways, we will be seen as effective partners with the faculty in promoting teaching and scholarship of this musical genre both in the immediate and the long term. 


\section{Works Consulted}

The author gratefully acknowledges interviews and/or correspondence with Daniel Bédard, Debra Ann Begg, Raymond Bisha, Heidi Bishop, Hoi Cheu, James Deaville, Sean Delaney, Kevin Donnelly, Patrick Dorian, Liz Dutton, Mark Evans, Daniel Goldmark, Richard Green, Robert Hall, Florence Hayes, Myrna Layton, Neil Lerner, Stephen Ryan, Warren Sherk, and Robynn Stilwell. Special thanks to Irene Golas for her critical input on this paper.

All web sites listed below were verified using Mozilla Firefox on July 5, 2010.

\section{Books, Articles and Web Sites}

Adorno, Theodor, and Hanns Eisler. 2007. Composing for the Films. With a new introduction by Graham McCann. London: Continuum. First published by Oxford University Press in 1947.

Anderson, Gillian B. 1993. "'Perfuming the Air with Music': The Need for Film Music Bibliography." Music Reference Services Quarterly 2 (1-2): 59-103.

Anderson, Gillian B., and Ronald H. Sadoff, comps. 2003. Music and Image Bibliography. http://pws.prserv.net/loosepoodle/AndrsonSadofBib.pdf

Bordwell, David, and Noël Carroll, eds. 1996. Post-Theory: Reconstructing Film Studies. Madison, WI: University of Wisconsin Press.

Bowman, Durrell. 2006. "Dark Mirrors and Dead Ringers: Music for Suspense Films About Twins." Intersections: Canadian Journal of Music 27 (1): 54-74.

Bozynski, Michelle Carole. 2004. Music in Canadian Visual Narrative: Musical Collaborations in Five Films of Atom Egoyan and Patricia Rozema. PhD thesis, Musicology, University of Toronto.

Brown, Royal S. 1994. Overtones and Undertones: Reading Film Music. Berkeley: University of California.

Buhler, James, David Neumeyer, and Rob Deemer. 2010. Hearing the Movies: Music and Sound in Film History. New York: Oxford University Press.

Burlingame, Jon. 2000. Sound and Vision: Sixty Years of Motion Picture Soundtracks. New York: Billboard Press.

Burt, George. 1994. The Art of Film Music: Special Emphasis on Hugo Friedhofer, Alex North, David Raksin, Leonard Rosenman. Boston: Northeastern University.

Cooke, Mervyn. 2001. "Film Music." In The New Grove Dictionary of Music and Musicians, 2nd ed., edited by Stanley Sadie and John Tyrrell, 8: 797-810. New York: Macmillan.

Cooke, Mervyn. 2008. A History of Film Music. Cambridge: Cambridge University Press. 
Copland, Aaron. 1989. What to Listen for in Music. New York, NY: McGraw-Hill. First published in 1939 and revised in 1957 . The 1957 edition, since reprinted many times, includes the chapter on film music.

Dargis, Manohla. 2010. "You Can Judge a Book by Its Movie." New York Times, Sunday, 25 April 2010: 8, 12, Arts \& Leisure section. [Article on the noted film-studies scholar, David Bordwell]

Davis, Richard. 1999. Complete Guide to Film Scoring: the Art and Business of Writing Music for Movies and TV. Boston: Berklee Press.

Davison, Annette. 2004. Hollywood Theory, Non-Hollywood Practice: Cinema Soundtracks in the 1980s and 1990s. Hampshire: Ashgate Publishing.

Denby, David. 2007. "Big Pictures: Hollywood Looks for a Future.” New Yorker, 8 Jan. 2007: 54-63.

Desjardins, Christian. 2006. Inside Film Music: Composers Speak. Los Angeles: Silman-James Press.

Dorian, Patrick, comp. 2010. Bibliography of Online Resources in Film Music. East Stroudsberg University of Pennsylvania. www.esu.edu/ pdorian/filmmusic.htm.

Flinn, Caryl. 1992. Strains of Utopia: Gender, Nostalgia, and Hollywood Film Music. Princeton: Princeton University Press.

Goldmark, Daniel. 2005. Tunes for 'Toons: Music and the Hollywood Cartoon. Berkeley: University of California Press.

Goldmark, Daniel, Lawrence Kramer and Richard Leppert, eds. 2007. Beyond the Soundtrack: Representing Music in Cinema. Berkeley: University of California Press.

Gorbman, Claudia. 1987. Unheard Melodies: Narrative Film Music. Bloomington: Indiana University Press. Includes a selected and annotated bibliography on film music (pp. 177-86).

Gorbman, Claudia, and Warren M. Sherk, eds. 2004. Film Music 2: History, Theory, Practice. Sherman Oaks, Calif.: Film Music Society Publication.

Harper, Graeme, ed. 2009. Sound and Music in Film and Visual Media: An Overview. New York: Continuum.

Hickman, Roger. 2006. Reel Music: Exploring 100 Years of Film Music. New York: W.W. Norton.

Huckvale, David. 2008. Hammer Film Scores and the Musical Avant-Garde. Jefferson, NC: McFarland.

Jenemann, David. 2007. Adorno in America. Minneapolis: University of Minnesota Press. Inglis, Ian, ed. 2003. Popular Music and Film. London: Wallflower Press. 
Kalinak, Kathryn. 1992. Settling the Score: Music and the Classical Hollywood Film. Madison: University of Wisconsin.

Karlin, Fred. 1994. Listening to Movies: The Film Lover's Guide to Film Music. Belmont, Calif.: Schirmer/Thomson Learning.

Karlin, Fred, and Rayburn Wright. 2004. On the Track: A Guide to Contemporary Film Scoring. $2^{\text {nd }}$ ed. New York: Routledge.

Kassabian, Annahid. 2001. Hearing Film: Tracking Identifications in Contemporary Hollywood Film Music. New York: Routledge.

Lamoureux, Jacques, and Gilles Potvin. 1981. "Film Scores." In Encyclopedia of Music in Canada, edited by Helmut Kallmann, Gilles Potvin, and Kenneth Winters. Toronto: University of Toronto Press.

- 1992. "Film Scores." In Encyclopedia of Music in Canada, 2nd ed., edited by Helmut Kallmann and Gilles Potvin. Toronto: University of Toronto Press.

-. "Film Scores." In The Encyclopedia of Music in Canada. Historica-Dominion. www.thecanadianencyclopedia.com. The bibliography is updated.

Larsen, Peter. 2008. Film Music. London: Reaktion. First published in Norway in 2005.

Lerner, Neil, ed. 2009. Music in the Horror Film: Listening to Fear. New York: Routledge.

Maley, Desmond. 1993. "Becoming a Subject Literature Expert: A Case Study in Gerontology." $R Q 33$ (2, Winter): 205-212.

Marks, Martin Miller. 1979. "Film Music: The Material, Literature, and Present State of Research." Notes. $2^{\text {nd }}$ series, 36 (2, December): 282-325.

-1997. Music and the Silent Film: Contexts and Case Studies, 1895-1924. New York, NY: Oxford University Press. The first chapter is a revised and updated version of Marks's 1979 article for Notes.

McCarty, Clifford, ed. 1989. Film Music I. New York: Garland Publishing.

Melnyk, George. 2004. One Hundred Years of Canadian Cinema. Toronto: University of Toronto Press.

Melnyk, George, ed. 2007. Great Canadian Film Directors. Edmonton: University of Alberta Press.

Menand, Louis. 2010. The Marketplace of Ideas: Reform and Resistance in the American University. New York: W.W. Norton. (Issues of our Time)

Mera, Miguel. 2007. Mychael Danna's The Ice Storm. Lanham, MD: Scarecrow Press.

Mera, Miguel, and David Burnand, eds. 2006. European Film Music. Hampshire: Ashgate. 
Morgan, David. 2000. Knowing the Score: Film Composers Talk about the Art, Craft, Blood, Sweat, and Tears of Writing for Cinema. New York: HarperEntertainment.

Morris, Peter. 1978. Embattled Shadows: A History of Canadian Cinema, 1895-1939. Montreal: McGill-Queen's University Press.

Pitman, Walter. 2002. Louis Applebaum: A Passion for Culture. Toronto: Dundurn Press.

Prendergast, Roy M. 1992. Film Music: A Neglected Art. $2^{\text {nd }}$ ed. New York: Norton. A $3^{\text {rd }}$ edition, co-written by Prendergast and Ronald H. Sadoff, is currently in preparation.

Rappé, Erno. 1925. Encyclopedia of Music for Pictures. New York: Belwin. Reprinted in 1974 by the Arno Press.

Romney, Jonathan, and Adrian Wootton, eds. 1995. Celluloid Jukebox: Popular Music and the Movies since the 50s. London: British Film Institute.

Russell, Mark, and James Young. 2000. Film Music: Screencraft. Boston: Focal Press.

Schelle, Michael. 1999. The Score: Interviews with Film Composers. $1^{\text {st }}$ ed. Los Angeles: Silman James Press.

Schifrin, Lalo. 2008. Mission Impossible: My Life in Music. Edited by Richard Palmer. Lanham, MD: Scarecrow Press. (Studies in Jazz; no. 56)

Slobin, Mark, ed. 2008. Global Soundtracks: Worlds of Film Music. Middletown, CT: Wesleyan University Press.

Smith, Jeff. 1998. The Sounds of Commerce: Marketing Popular Film Music. New York: Columbia University Press.

Sonnenschein, David. 2001. Sound Design: The Expressive Power of Music, Voice, and Sound Effects in Cinema. Studio City, CA: Michael Weise Productions.

Stilwell, Robynn J. 2002. "Music in Films: A Critical Review of Literature, 1980-1996." Journal of Film Music 1 (1, Summer): 19-61.

Swynnoe, Jan G. 2002. The Best Years of British Film Music, 1936-1958. Woodbridge: Boydell Press.

Thomas, Tony. 1997. Music for the Movies. $2^{\text {nd }}$ ed. Los Angeles: Silman-James.

Timm, Larry. 2003. The Soul of Cinema: An Appreciation of Film Music. Upper Saddle River, NJ: Prentice-Hall. [According to WorldCat, Timm's book was first published by Simon \& Schuster in 1998, with a revised first edition issued by Pearson Custom the same year. The 2003 edition is greatly expanded to 346 pages from the 179 pages of the 1998 editions. I consulted only the 2003 edition.]

Wescott, Steven D., comp. 1985. A Comprehensive Bibliography of Music for Film and Television. Detroit: Information Coordinators. 
White, Jerry, ed. 2006. The Cinema of Canada. London: Wallflower Press. (24 Frames)

Wierzbicki. James. 2009. Film Music: A History. New York: Routledge.

\section{Journals}

Journal of Film Music. London: Equinox Press. www.equinoxjournals.com/JFM

Music and the Moving Image. Illinois University Press. www.press.uillinois.edu/journals/mmi.html

Music, Sound, and the Moving Image. Liverpool University Press. www.liverpool-unipress.co.uk/html/publication.asp?idProduct=3727

\section{Video Recordings}

Guild of Canadian Film Composers. 2006. And Now...The Seminars. Toronto: Guild of Canadian Film Composers.

Lieberstein, Dan, dir. 2007. Lights, Action, Music. Los Angeles: First Look Pictures.

Waletzky, Joshua, dir. 2007. Music for the Movies - Bernard Herrmann. West Long Branch, NJ: Kultur. Originally released in 1992. 2007. Music for the Movies - The Hollywood Sound. West Long Branch, NJ: Kultur. Originally released in 1995.

\section{Publishers}

Ashgate Publishing. Popular and Folk Music Series. www.ashgate.com/popularandfolkmusicseries

Cambridge University Press. www.cambridge.org/uk/

Continuum. www.continuumbooks.com/

Edinburgh University Press. Music and Moving Image Series. www.euppublishing.com/series/MAMI

Equinox Books. www.equinoxpub.com/books/main.asp

McFarland Publishing. www.mcfarlandpub.com/ 
Oxford University Press. Music, Popular Song, and Film Music.

www.oup.com/us/catalog/general/subject/Music/PopularMusic/MusicTheatrePopularSongFilm Music/

Music/Media Series. www.oup.com/us/catalog/general/series/OxfordMusicMediaSeries/

Routledge. Music and Screen Media Series.

www.routledge.com/books/series/routledge_music_and_screen_media_series_RMSM/

Scarecrow Press. Film Score Guides series. www.scarecrowpress.com

University of California Press. Cinema \& Performing Arts.

www.ucpress.edu/subject.php?sc=cinmaj

University of California Press. Music. www.ucpress.edu/subject.php?sc=musmaj

\section{Forthcoming Publications}

Cooke, Mervyn, ed. 2010. The Hollywood Film Music Reader. Oxford University Press (forthcoming in August).

Deaville, James, ed. 2011. Music in Television. Routledge.

Evans, Mark, ed. 2011-13. Encyclopedia of Film, Music and Sound. 3 v. Equinox Books.

Hubbert, Julie, ed. 2011. Celluloid Symphonies: Texts and Contexts in Film Music History. University of California Press.

Pool, Jeannie Gayle, and H. Stephen Wright. 2010. A Research Guide to Film and Television Music in the United States. Scarecrow Press.

Railton, Diane and Paul Watson. 2011. Music Video and the Politics of Representation. Edinburgh University Press.

Sherk, Warren M., comp. 2010. Film Music: A Guide to Books, Articles and Composer Interviews. Scarecrow Press (forthcoming in August).

Stilwell, Robynn, and Peter Franklin, eds. 2011. Cambridge Companion to Film Music. Cambridge University Press. 